\title{
Dentifrices for children differentially affect cell viability in vitro
}

\author{
Barbara Cvikl $^{1,2} \cdot$ Adrian Lussi $^{1} \cdot$ Andreas Moritz $^{2} \cdot$ Reinhard Gruber $^{1,3}$
}

Received: 28 September 2015 / Accepted: 28 March 2016/Published online: 6 April 2016

(C) The Author(s) 2016. This article is published with open access at Springerlink.com

\begin{abstract}
Objectives Child dentifrices vary in their composition, with possible differential impacts on cells in the oral soft tissue. While cytotoxicity studies have been performed on adult dentifrices, no respective studies have thus far been reported on child dentifrices.

Material and methods Seventeen commercial dentifrices for children up to 12 years of age were evaluated with respect to their in vitro cytotoxicity on gingival fibroblasts, oral squamous cell carcinoma HSC-2 cells, and L929 mouse fibroblasts. Proliferation was analyzed and live-dead staining was performed.

Results Ten child dentifrices greatly reduced cell viability with LC50 values below $5 \%$. Four dentifrices showed a moderate cytotoxicity with LC50 values between 5 and $20 \%$. Three child dentifrices showed almost no cytotoxicity with LC50 values above $95 \%$. The results of the assays for proliferation and live-dead staining supported these findings. Conclusions The different composition of the child dentifrices translated into a broad spectrum of in vitro cytotoxicity on cells of the oral cavity.
\end{abstract}

Barbara Cvikl

barbara.cvik1@zmk.unibe.ch

1 Department of Preventive, Restorative and Pediatric Dentistry, School of Dental Medicine, University of Bern, Freiburgstrasse 7, CH-3010 Bern, Switzerland

2 Department of Conservative Dentistry \& Periodontology, Medical University of Vienna, Sensengasse 2a, A-1090 Vienna, Austria

3 Department of Oral Biology, Medical University of Vienna, Sensengasse 2a, A-1090 Vienna, Austria
Clinical relevance The in vitro data provide the scientific foundation for further in vivo research testing the clinical relevance of the present findings.

Keywords Children · Toothpaste $\cdot$ Dentifrices . Cytotoxicity $\cdot$ In vitro

\section{Introduction}

Children with caries in their primary teeth suffer three times more from caries in their permanent teeth than their peers of the same age [1]. The most important factor in preventing the development of caries and reducing its incidence is regular and supervised tooth brushing with fluoride dentifrices [2]. Children, however, are neither motivated nor skilled enough to brush their teeth effectively [3]. Consequently, parents ideally supervise their children's tooth brushing or brush their teeth when they are very young. This is also important since young children ingest up to $65 \%$ of the toothpaste $[4,5]$ due to a not-yet mature swallowing reflex [6]. Despite the recommendations to use a pea-sized amount of toothpaste for one tooth-brushing event, parents may use a larger amount [3]. The need for special child dentifrices is further supported by the fact that a majority of mothers use the same toothpaste for their children as for themselves [5]. Furthermore, it is shown that brushing time is prolonged when the dentifrices is good tasting and a pleasant consistency [7]. Changing behavioral factors at a young age toward good hygienic practices has been shown to lead to better oral health for a lifetime [8]. But the taste and the consistency of toothpaste are not the only differences between available products for adults and children. The ideal product for children should provide maximal fluoride availability, minimal abrasivity, and ingredients that will not interfere with fluoride delivery and assure a pleasant 
brushing experience [9]. It should also be distinguished if the children already have a mixed dentition. With a mixed dentition toothpastes should perform higher levels of foam, higher amounts of fluoride and other tastes [9]. However, the effect of dentifrices and their ingredients on cells of the oral cavity may also be important, since they are in direct contact with these respective tissues during and also after brushing.

To avoid the compromising of child's health, the American and European Academies of Pediatric Dentistry (AAPD and EAPD) published recommendations for the correct use of dentifrices [10]. The recommendations refer only to the fluoride content, since the beneficial and also potential adverse effects of fluorides have been well investigated [2]. The main fluoride intake of young children occurs through ingestion of fluoridated dentifrices $[11,12]$. In order to reduce the risk of fluorosis in developing permanent teeth, international recommendations are the use of $1000 \mathrm{ppm}$ of fluoride for children under 6 years and up to $1500 \mathrm{ppm}$ for older children [13]. Fluoride, however, is not the only ingredient that is ingested by children when toothpaste is swallowed. Dentifrices contain a wide range of different ingredients, each with a special purpose, but some also with the potential to negatively affect the oral mucosa.

The oral mucosal sensitivity and contact stomatitis are reported to arise as a result of different toothpaste ingredients such as abrasives, detergents, binding agents, humectants, preservatives, coloring agents, antiseptics, fluoride salts, and flavorings in sensitive individuals [14]. In particular, triclosan, known for its antibacterial and antiplaque effect, and sodium lauryl sulfate, a common detergent, are cited as offending ingredients. Clinical intraoral adverse effects such as burning mouth sensations, epithelial desquamation, and recurrent aphtous ulcerations $[15,16]$, as well as reduced cell viability in in vitro investigations point to possible issues with the diverse ingredients used in adult dentifrices [17]. No study so far has examined the influence of child dentifrices on cells of the oral cavity. Therefore, the aim of this study was to investigate the effect of 17 commercial child dentifrices on cells of the oral mucosa and on cells commonly used for cytotoxicity testing. The working hypothesis was that the soluble compounds of dentifrices especially designed for children do not change cell viability compared to the control.

\section{Material and Methods}

\section{Cell culture and stimulation of cells}

Epithelial cells and gingival fibroblasts, which may come in contact with toothpaste in the oral cavity, as well as a L929 cell line which is commonly used for cytotoxicity testing, were used for the main experiments on cell viability. Furthermore, gingival fibroblasts were used in indicated experiments for live-dead cell staining and proliferation assays. For experiments with primary cells (gingival fibroblasts), cell pools made from cells of three different donors were used to minimize donor variability. Cells were prepared from tissue grafts after wisdom tooth extraction in healthy individuals. Before the extraction, the patients were informed about the possibility of using their teeth together with adhering tissue for research purposes and consent was obtained (Kantonale Ethikkommission Bern). Oral squamous cell carcinoma cell line HSC-2 (the source of epithelial cells) was kindly provided by Dr. Rausch-Fan from the Medical University of Vienna, Austria. Murine L929 fibrosarcoma cells were kindly provided by Dr. Erik Hedbom, School of Medical Dentistry, University of Bern, Switzerland. Cells were cultivated in a humidified atmosphere in Dulbecco's Modified Eagle Medium (DMEM, Invitrogen Corporation, Carlsbad, CA, USA) supplemented with $10 \%$ fetal bovine serum (FCS; PAA Laboratories, Linz, Austria) and antibiotics (Invitrogen) at $37{ }^{\circ} \mathrm{C}$ and $5 \% \mathrm{CO}_{2}$. For experiments on cell viability and proliferation assays, cells were seeded in microtiter plates (Greiner Bio-One GmbH, Frickenhausen, Germany) at $30,000 \mathrm{cells} / \mathrm{cm}^{2} 1$ day before stimulation with the soluble compounds of child dentifrices. For live-dead cell staining, cells were seeded onto chamber slides (Thermo Scientific Nunc, Waltham, MA, USA) under the same conditions as the other assays.

\section{Stimulation with the soluble compounds of child dentifrices}

The child dentifrices investigated in the study were Blendi up to 6 years (Blend-a-Med, Procter \& Gamble Co., Cincinnati, OH, USA), Candida Kids up to 6 years (Mibelle AG, Switzerland), Candida Junior 6-12 years (Mibelle AG, Switzerland), Colgate ${ }^{\circledR}$ 2-6 years (Colgate-Palmolive, New York, NY, USA), Dontodent Kids up to 6 years (dm-drogerie markt GmbH, Karlsruhe, Germany), Dontodent Junior 6 years plus (dm-drogerie markt GmbH, Karlsruhe, Germany), Elmex ${ }^{\circledR}$ up to 6 years (GABA International AG, ColgatePalmolive), Elmex® Junior 6-12 years (GABA International AG, Colgate-Palmolive), Mentadent Kids up to 6 years (Unilever Austria GmbH, Vienna, Austria), nenedent ${ }^{\circledR}$ baby 0.5-2 years (Dentinox, Berlin, Germany), nenedent ${ }^{\circledR}$ Kinderzahncreme up to 6 years (Dentinox), Odol-med3 () Milchzahn 0.5-5 years (GlaxoSmithKline, Brentford, UK), Odol-med3® Milchzahn up to 6 years (GlaxoSmithKline), Odol-med3® Junior 6 years plus (GlaxoSmithKline), Sensodyne ${ }^{\circledR}$ Junior 6 years plus (GlaxoSmithKline), mein kleines Theramed up to 6 years (Henkel AG \& Co. KGaA, Düsseldorf, Germany), and Theramed Junior 6 years plus (Henkel AG \& Co. KGaA). Detailed information on the dentifrices used in the study is given in Table 1. In order to 
Table 1 Dentifrices used in the present study

\begin{tabular}{|c|c|c|c|c|}
\hline Toothpaste (Company) & Detergents & Composition & Expiry date & $\begin{array}{l}\text { Country of } \\
\text { purchase }\end{array}$ \\
\hline $\begin{array}{l}\text { Blendi blend-a-med -6 } \\
\text { (Procter \& Gamble UK, } \\
\text { Weybridge, KT13 OXP, UK) }\end{array}$ & Cocamidopropyl Betaine & $\begin{array}{l}\text { Aqua, Aroma, Benzyl Alcohol, Carbomer, } \\
\text { Cochineal Red, Hydrated Silica, Mica, } \\
\text { Sodium Chloride, Sodium Saccharin, } \\
\text { Sodium Fluoride (500 ppm), Sodium } \\
\text { Phosphate, Sorbitol, Titandioxid, } \\
\text { Trisodium Phosphate, Xanthan Gum }\end{array}$ & $01 / 2016$ & Austria \\
\hline $\begin{array}{l}\text { Candida Kids 0-6 } \\
\text { (Migros, Mibelle AG, } \\
\text { Buchs, Switzerland) }\end{array}$ & Sodium-Coco-Sulfate & $\begin{array}{l}\text { Aqua, Aroma, Calcium Glycerophosphate, } \\
\text { Cellulose Gum, Citral, Hydrated Silica, } \\
\text { Hydrogenated Starch Hydrolysate, } \\
\text { Iron Oxides Limonene, Linalool, Mica, } \\
\text { Sodium Hydroxide, Sodium Saccharin, } \\
\text { Sodium Monofluorphosphate (500 ppm), } \\
\text { Titandioxid }\end{array}$ & $09 / 2015$ & Switzerland \\
\hline $\begin{array}{l}\text { Candida Junior 6-12 } \\
\text { (Migros, Mibelle AG, } \\
\text { Buchs, Switzerland) }\end{array}$ & Sodium-Coco-Sulfate & $\begin{array}{l}\text { Aqua, Aroma, Cellulose Gum, Dicalcium } \\
\text { Phosphate, Hydrated Silica, Hydrogenated } \\
\text { Starch Hydrolysate, Limonene, Sodium } \\
\text { Hydroxide, Sodium Saccharin, Sodium } \\
\text { Monofluorphosphate (1400 ppm), Titandioxid }\end{array}$ & $01 / 2016$ & Switzerland \\
\hline $\begin{array}{l}\text { Colgate }{ }^{8} 2-6 \\
\text { (Colgate-Palmolive, } \\
\text { New York, NY, USA) }\end{array}$ & Sodium Lauryl Sulfate & $\begin{array}{l}\text { Aqua, Aroma, Brilliant Blue FCF, Cellulose } \\
\text { Gum, Glycerin, Hydrated Silica, Limonene, } \\
\text { Mica, Polyethylene, Polyethylenglycol, } \\
\text { Sodium Fluoride (1000 ppm), Sodium } \\
\text { Saccharin, Sorbitol, Titandioxid }\end{array}$ & $08 / 2015$ & Austria \\
\hline $\begin{array}{l}\text { Dontodent }{ }^{\mathrm{DM}} \text { Kids }-6 \\
\text { (dm-drogerie markt, } \\
\text { Karlsruhe, Germany) }\end{array}$ & $\begin{array}{l}\text { Cocamidopropyl Betaine, } \\
\text { Sodium C14-16 Olefin } \\
\text { Sulfonate }\end{array}$ & $\begin{array}{l}\text { Aqua, Aroma, Cellulose Gum, Cochineal Red } \\
\text { Hydrated Silica, Mica, Sodium Chloride, } \\
\text { Sodium Saccharin, Sodium Fluoride } \\
\text { (500 ppm), Sorbitol, Titandioxid }\end{array}$ & 09/2016 & Austria \\
\hline $\begin{array}{l}\text { Dontodent }{ }^{\mathrm{DM}} \text { Junior } 6 \text { plus } \\
\text { (dm-drogerie markt, } \\
\text { Karlsruhe, Germany) }\end{array}$ & $\begin{array}{l}\text { Sodium C14-16 Olefin } \\
\quad \text { Sulfonate }\end{array}$ & $\begin{array}{l}\text { Aqua, Aroma, Brilliant Blue FCF, Calcium } \\
\text { Glycerophosphate, Hydrated Silica, Limonene, } \\
\text { Mica, Sodium Saccharin, Sodium Fluoride } \\
\text { (1000 ppm), Sorbitol, Titandioxid, } \\
\text { Xanthan Gum }\end{array}$ & 09/2016 & Austria \\
\hline $\begin{array}{l}\text { Elmex®Kinderzahnpasta }-6 \\
\text { (GABA International AG, } \\
\text { Colgate-Palmolive) }\end{array}$ & $\begin{array}{l}\text { Cocamidopropyl Betaine, } \\
\text { Aminfluorid (500 ppm) }\end{array}$ & $\begin{array}{l}\text { Aqua, Aroma, Hydrated Silica, Hydrochoric Acid, } \\
\text { Hydroxyethylcellulose, Limonene, Sodium } \\
\text { Saccharin, Sorbitol, Titandioxid }\end{array}$ & $12 / 2015$ & Austria \\
\hline $\begin{array}{l}\text { Elmex® Junior 6-12 } \\
\text { (GABA International } \\
\text { AG, Colgate-Palmolive) }\end{array}$ & Aminfluorid (1400 ppm) & $\begin{array}{l}\text { Aqua, Aroma, Hydrated Silica, Hydrochoric Acid, } \\
\text { Hydroxyethylcellulose, Limonene, Sodium } \\
\text { Saccharin, Sorbitol/Glycerin, Titandioxid }\end{array}$ & $12 / 2015$ & Austria \\
\hline $\begin{array}{l}\text { Mentadent Kids 3-6 } \\
\text { (Unilever Dept ER } \\
\text { Wirral, JW, UK) }\end{array}$ & Sodium Lauryl Sulfate & $\begin{array}{l}\text { Aqua, Aroma, Calcium Gluconate, Cellulose } \\
\text { Gum, Glycerin, Hydrated Silica, Phthalocyanine } \\
\text { Blue, Polyethylenglycol, Sodium Saccharin, } \\
\text { Sodium Fluorid (1000 ppm), Sorbitol, Titandioxid, } \\
\text { Tocopheryl Acetate }\end{array}$ & $11 / 2015$ & Austria \\
\hline $\begin{array}{l}\text { nenedent }{ }^{\circledR} \text { baby } 0.5-2 \\
\text { (Dentinox®, Berlin, } \\
\text { Germany) }\end{array}$ & Sodium Lauryl Sarcosinate & $\begin{array}{l}\text { Aqua, Aroma, Disodium EDTA, Glycerin, } \\
\text { Hydrated Silica, Propylene Glycol, Sodium } \\
\text { Monofluorphosphate (500 ppm), Sodium Chloride, } \\
\text { Titandioxid, Xanthan Gum, Xylitol }\end{array}$ & $08 / 2015$ & Austria \\
\hline $\begin{array}{l}\text { Nenedent }{ }^{\circledR}-6 \\
\text { (Dentinox®, } \\
\text { Berlin, Germany) }\end{array}$ & Sodium Lauryl Sarcosinate & $\begin{array}{l}\text { Aqua, Aroma, Disodium EDTA, Glycerin, } \\
\text { Hydrated Silica, Propylene Glycol, Sodium } \\
\text { Monofluorphosphate (500 ppm), Sodium } \\
\text { Chloride, Titandioxid Xanthan Gum, Xylitol }\end{array}$ & $08 / 2016$ & Austria \\
\hline $\begin{array}{l}\text { Odol-med3® } 0.5-5 \\
\text { (GlaxoSmithKline, } \\
\text { Brentford, UK) }\end{array}$ & $\begin{array}{l}\text { Cocamidopropyl Betaine, } \\
\text { Sodium Methyl Cocoyl } \\
\text { Taurate }\end{array}$ & $\begin{array}{l}\text { Aqua, Aroma, Carrageenan, Glycerin, } \\
\text { Hydrated Silica, Limonene, Phthalocyanine } \\
\text { Blue, Sodium Saccharin, Sodium Fluorid (500 ppm), } \\
\text { Sorbitol, Thioindigo, Titandioxid, Xanthan Gum }\end{array}$ & $01 / 2016$ & Austria \\
\hline $\begin{array}{l}\text { Odol-med3® } 0-6 \\
\text { (GlaxoSmithKline, } \\
\text { Brentford, UK) }\end{array}$ & $\begin{array}{l}\text { Sodium Methyl Cocoyl } \\
\text { Taurate }\end{array}$ & $\begin{array}{l}\text { Aqua, Aroma, Disodium Phosphate, Glycerin, } \\
\text { Hydrated Silica, Phthalocyanine Blue, } \\
\text { Methylparaben, Polyethylenglycol, Propylparaben, } \\
\text { Sodium Saccharin, Sodium Fluorid (500 ppm), } \\
\text { Thioindigo, Titandioxid, Xylitol, Xanthan Gum }\end{array}$ & $01 / 2016$ & Austria \\
\hline
\end{tabular}


Table 1 (continued)

\begin{tabular}{|c|c|c|c|c|}
\hline Toothpaste (Company) & Detergents & Composition & Expiry date & $\begin{array}{l}\text { Country of } \\
\text { purchase }\end{array}$ \\
\hline $\begin{array}{l}\text { Odol-med3® Junior } 6 \text { plus } \\
\text { (GlaxoSmithKline, } \\
\text { Brentford, UK) }\end{array}$ & $\begin{array}{l}\text { Cocamidopropyl Betaine, } \\
\text { Sodium Methyl Cocoyl } \\
\text { Taurate }\end{array}$ & $\begin{array}{l}\text { Aqua, Aroma, Carrageenan, Glycerin, } \\
\text { Hydrated Silica, Limonene, Phthalocyanine } \\
\text { Blue, Sodium Saccharin, Sodium Fluorid } \\
\text { (1450 ppm), Sorbitol, Thioindigo, Titandioxid, } \\
\text { Xanthan Gum }\end{array}$ & & \\
\hline $\begin{array}{l}\text { Sensodyne® Junior } 6 \text { plus } \\
\text { (GlaxoSmithKline) }\end{array}$ & Cocamidopropyl Betaine & $\begin{array}{l}\text { Aqua, Aroma, Glycerin, Hydrated Silica, } \\
\text { Limonene, Polyethylenglycol, Sodium Fluorid } \\
\text { (1450 ppm), Sodium Hydroxide, Sodium Saccharin, } \\
\text { Sorbitol, Sucralose, Titandioxid, Xanthan Gum }\end{array}$ & $08 / 2015$ & Austria \\
\hline $\begin{array}{l}\text { Theramed Junior 1-6 } \\
\text { (Henkel AG, Düsseldorf, } \\
\text { Germany) }\end{array}$ & Cocamidopropyl Betaine & $\begin{array}{l}\text { Aqua, Aroma, Azorubine, Calcium Glycerophosphate, } \\
\text { Cellulose Gum, Disodium Phosphate, Glycerin, } \\
\text { Hydrated Silica, Methylparaben, Sodium Chloride, } \\
\text { Sodium Fluorid (500 ppm), Sodium Saccharin, } \\
\text { Sorbitol }\end{array}$ & $09 / 2015$ & Austria \\
\hline $\begin{array}{l}\text { Theramed Junior } 6 \text { plus } \\
\text { (Henkel AG, Düsseldorf, } \\
\text { Germany) }\end{array}$ & $\begin{array}{l}\text { Sodium Lauryl Sulfate, } \\
\text { Cocamidopropyl } \\
\text { Betaine }\end{array}$ & $\begin{array}{l}\text { Aqua, Aroma, Azorubine, Calcium Glycerophosphate, } \\
\text { Disodium Phosphate, Glycerin, Hydrated Silica, } \\
\text { Propylen Glycol, Mica, Methylparaben, Sodium } \\
\text { Chloride, Sodium Fluorid (1000 ppm), Sodium } \\
\text { Saccharin, Sodium Sulfate, Sorbitol, Titandioxid, } \\
\text { Xanthan Gum }\end{array}$ & $09 / 2015$ & Austria \\
\hline
\end{tabular}

extract the soluble compounds of the toothpaste, toothpaste slurries were made with serum-free medium $(50 \% \mathrm{w} / \mathrm{v})$ in sealable plastic tubes with a magnetic stirrer bar at $350 \mathrm{rpm}$. Afterwards, the slurry was centrifuged at $16,000 \times \mathrm{g}$ for $10 \mathrm{~min}$ and soluble compounds (toothpaste-conditioned medium; TCM) were collected and filter sterilized as described elsewhere [17]. Sensodyne ${ }^{\circledR}$ Junior 6 , Theramed -6 , and Blendi -6 were diluted less $(80 \% \mathrm{w} / \mathrm{v})$, since the calculation of the half lethal concentration (LC50) was not possible otherwise. Directly before stimulation of the cells, 50 and $80 \%$ toothpaste-conditioned medium was further diluted up to a final concentration of $0.4 \%$.

\section{Cell viability and calculation of the half lethal concentration}

The TCM of 17 different child dentifrices was used at concentrations of 50 and $80 \%$ and diluted up to a final concentration of $0.4 \%$ for stimulating gingival fibroblasts (GF), epithelial cells (HSC-2), and murine fibrosarcoma cells (L929). After 2 min of stimulation, the recommended as well as applied average time for tooth brushing [18, 19], cells were washed with phosphate-buffered saline (PBS) to neutralize the further effects of the TCM on the cells, and serum-free media was added containing MTT (3-[4,5-dimethythiazol-2-yl]-2,5diphenyltetrazolium bromide, $0.5 \mathrm{mg} / \mathrm{ml}$, Sigma-Aldrich, St. Louis, MO, USA) for $2 \mathrm{~h}$ at $37{ }^{\circ} \mathrm{C}$. Optical density of formazan crystals, formed by NAD(P)H-dependent oxidoreductases and dissolved in dimethyl sulfoxide, was measured with a microplate reader (EL 808, Biotek Instruments, Winooski, VT, USA) and normalized to untreated cells. The
LC50 was calculated by an exponential regression analysis using the formula $\mathrm{y}=\mathrm{m}^{*} \mathrm{e}^{\wedge}\left(\mathrm{b}^{*} \mathrm{x}\right)$ as described elsewhere [17]. Furthermore, toothpaste slurries $(25,12$, and $6 \% \mathrm{w} / \mathrm{v})$ were directly used for stimulating oral fibroblasts and subsequent viability measurements were performed in indicated experiments.

\section{Cell proliferation assay}

Cell proliferation was measured by incorporation of 5 bromo-2'-deoxyuridine (BrdU) using the Cell Proliferation ELISA, BrdU (colorimetric) kit from Roche (Basel, Switzerland). The TCM of 17 different child dentifrices, at a concentration of $5 \%$, was used for stimulating gingival fibroblasts. After 2 min of stimulation, cells were washed with PBS, and serum-free media was added containing 5-bromo-2'-deoxyuridine. After $2 \mathrm{~h}$, the BrdU incorporation was determined according the manufacturer's instructions and normalized to untreated cells.

\section{Live-dead cell staining}

The TCM of 17 different child dentifrices at a concentration of $5 \%$ was used for stimulating gingival fibroblasts. After 2 min of stimulation, cells were washed with PBS, and a cell permeable green fluorescent dye to stain live cells was added. Dead cells were stained by propidium iodide, a red fluorescent dye, which in viable cells is actively pumped out of the cytoplasm. Visualization was performed using fluorescence microscopy. 


\section{Statistical analysis}

Data on the LC50 of the different child dentifrices were reported by the mean and standard deviation of four independent experiments, each performed in duplicate. Differences in LC50 between cells treated with the 17 different TCM were tested using one-way ANOVA followed by a post hoc TukeyHSD test (SPSS version 19.0, SPSS Inc., Chicago, IL, USA). An alpha of $5 \%$ was considered significant. Data on the cell proliferation (BrdU incorporation) were described by the mean and standard deviation.

\section{Results}

\section{Child dentifrices differentially affect cell viability}

The LC50 data of TCM from 17 different child dentifrices after stimulating gingival fibroblasts for 2 min, measured by the capacity of the cells to convert MTT into formazan crystals, are shown in Fig. 1. Based on these data, three groups of LC50 values showed statistically significant differences: (i) child dentifrices exhibiting an LC50 below $5 \%$ were Dontodent $6+$, Mentadent Kids -6 , Candida -6 , Theramed 6+, Elmex ${ }^{\circledR} 6+$, Colgate ${ }^{\circledR}-6$, Dontodent -6 , Odol-med3 ${ }^{\circledR} 6+$, Candida 6+, and Odol-med3 ${ }^{\circledR}-6$; (ii) child dentifrices exhibiting an LC50 between 5 and $20 \%$ were Elmex ${ }^{\circledR}-6$, Odol-med $3 \AA-5$, nenedent ${ }^{\circledR}$ baby -2 , and nenedent ${ }^{\circledR}-6$; (iii) child dentifrices exhibiting an LC50 above $95 \%$ were Sensodyne ${ }^{\circledR} 6+$, Theramed -6 , and Blendi -6 . LC50 data after stimulating epithelial cells (HSC-2) and murine fibrosarcoma cells (L929) for 2 min are shown in Table 2 and confirm the data obtained on gingival fibroblasts. Together, these observations suggest that the majority of child dentifrices substantially reduce the viability of cells. Some child dentifrices, however, affect the viability less or not at all. By comparing dentifrices from the same manufacturers with regard to the age groups for which they are prepared, a consistent picture appeared. Child dentifrices for younger children below 6 years of age resulted in higher LC50 values than their comparable dentifrices for children above 6 years. This is true for Dontodent, Elmex ${ }^{\circledR}$, Theramed, and Odol-med3®; but not so for Candida.

The results of the viability testing when fibroblasts were stimulated with the uncentrifuged and unfiltered toothpaste slurry are shown in Fig. 2. The 25 and $12 \%$ concentrations of uncentrifuged and unfiltered toothpaste slurries strongly reduced cell viability, almost independent of the toothpaste used. When using a $6 \%$ concentration, the results mainly support the data of the experiments when toothpaste-conditioned medium was used.

\section{Child dentifrices differentially affect cell proliferation}

In parallel, the incorporation of BrdU in the DNA of gingival fibroblasts after stimulating the cells with $5 \% \mathrm{TCM}$ from the 17 different child dentifrices was investigated (Fig. 3). The mean values for the dentifrices that showed an LC50 below $5 \%$ (i) were between 0.4 and 0.7 , compared to the unstimulated control with 1.0. Mean values for dentifrices from the group with an LC50 between 5

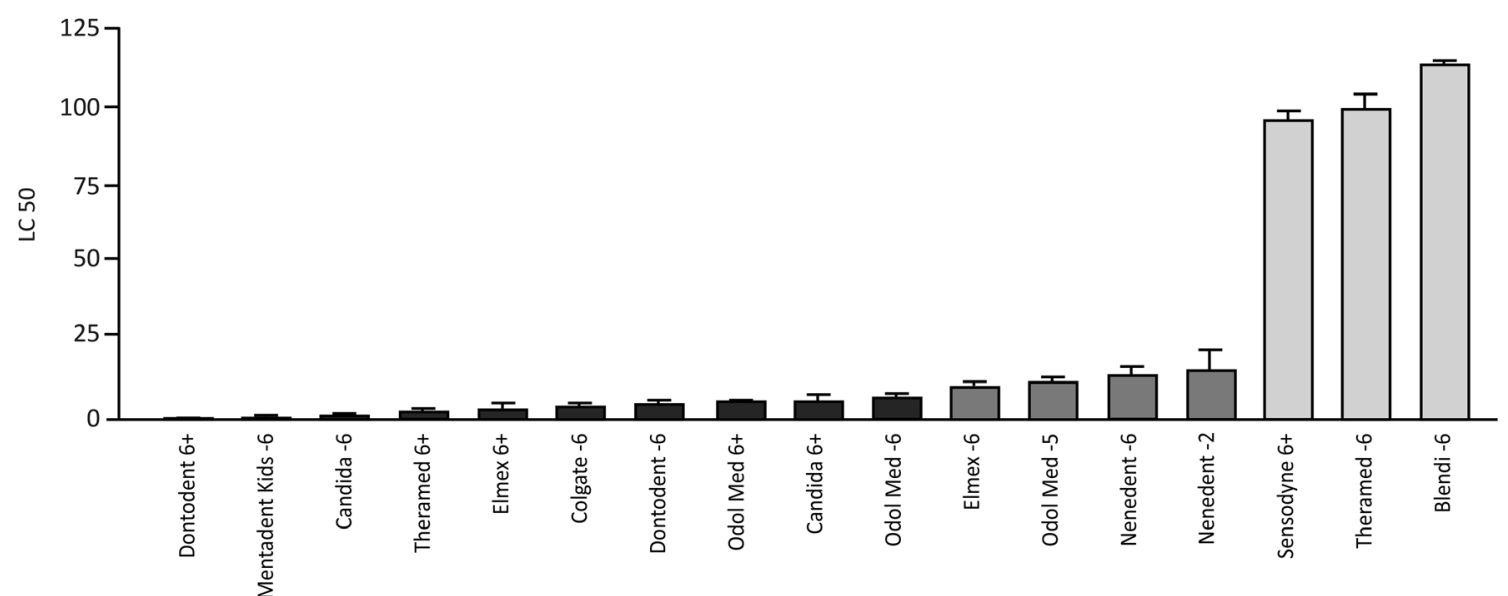

Fig. 1 LC50 of gingival fibroblasts after stimulation with different concentrations of the soluble compounds from child dentifrices. Oral fibroblasts were exposed for $2 \mathrm{~min}$ to various concentrations of the soluble compounds from child dentifrices. Viability was measured with an MTT assay and the LC50 were calculated, resulting in three groups that differed statistically significantly. Child dentifrices exhibiting an LC50 below $5 \%$ were Dontodent $6+$, Mentadent Kids -6 , Candida -6 ,
Theramed 6+, Elmex 6+, Colgate -6 , Dontodent -6 , Odol med 6+, Candida $6+$, and Odol med -6 (black bars); child dentifrices exhibiting an LC50 between 5 and $20 \%$ were Elmex -6, Odol med -5, nenedent ${ }^{\circledR}$ baby -2 , and Nenedent -6 (dark-gray bars); child dentifrices exhibiting an LC50 above $95 \%$ were Sensodyne $6+$, Theramed -6 , and Blendi -6 (light-gray bars) 
Table 2 LC50 of epithelial cells and murine fibroblasts after stimulation with different concentrations of TCM

\begin{tabular}{|c|c|c|c|c|}
\hline & \multicolumn{2}{|c|}{ Human Sarcoma Cells } & \multicolumn{2}{|l|}{ L929 } \\
\hline & Mean & Standard deviation & Mean & Standard deviation \\
\hline Dontodent ${ }^{\mathrm{DM}}$ Junior $6+$ & 0.27 & 0.36 & 0.57 & 0.82 \\
\hline Mentadent Kids 3-6 & 2.04 & 0.95 & 2.62 & 0.67 \\
\hline Candida Kids $0-6$ & 1.07 & 0.45 & 1.70 & 1.12 \\
\hline Theramed Junior 6+ & 1.52 & 0.82 & 2.09 & 0.51 \\
\hline Elmex ${ }^{\circledR}$ Junior 6-12 & 6.00 & 1.40 & 0.81 & 0.51 \\
\hline Colgate ${ }^{\circledR} 2-6$ & 3.09 & 0.94 & 3.52 & 0.80 \\
\hline Dontodent ${ }^{\mathrm{DM}}$ Kids -6 & 2.44 & 0.53 & 2.25 & 0.45 \\
\hline Odol-med3® Junior 6+ & 2.53 & 0.40 & 2.72 & 0.97 \\
\hline Candida Junior 6-12 & 1.32 & 0.39 & 2.16 & 0.96 \\
\hline Odol-med3® 0-6 & 6.08 & 1.08 & 5.12 & 3.04 \\
\hline Elmex ${ }^{\circledR}-6$ & 7.03 & 4.57 & 8.70 & 5.57 \\
\hline Odol-med3® $0.5-5$ & 7.91 & 0.97 & 7.04 & 1.62 \\
\hline Nenedent ${ }^{\circledR}-6$ & 9.11 & 2.29 & 8.76 & 1.83 \\
\hline nenedent $₫$ baby $0.5-2$ & 7.58 & 5.22 & 14.22 & 10.01 \\
\hline Sensodyne® Junior 6+ & 110.92 & 27.13 & 88.73 & 7.56 \\
\hline Theramed Junior 1-6 & 97.26 & 19.05 & 97.82 & 22.89 \\
\hline Blendi blend-a-med -6 & 107.22 & 8.74 & 92.12 & 8.90 \\
\hline
\end{tabular}

and $20 \%$ (ii) and above $95 \%$ (iii) were between 0.9 and 1.2 and between 0.7 and 1.2 , respectively. Together these data support the results from the viability testing.

\section{Live-dead cell staining of fibroblasts after stimulation with child dentifrices}

Consistent with the results of the viability testing and the proliferation assay, stimulation with the TCM of child dentifrices at a concentration of $5 \%$ resulted in different ratios of living cells (green) to dead cells (red) depending on the respective TCM (Fig. 4). Cells stimulated with a TCM from dentifrices with an LC50 above $95 \%$ mostly appeared green, which was similar to the unstimulated control group. In addition, the dentifrices from the groups with an LC50 between 5 and $20 \%$ and an LC50 below $5 \%$ supported the results of the viability and the proliferation assays in the live-dead staining. In the group with an LC50 between 5 and $20 \%$, green cells were visible beside the red cells. In the group with an LC50 below $5 \%$, mostly red cells were visible, if any.

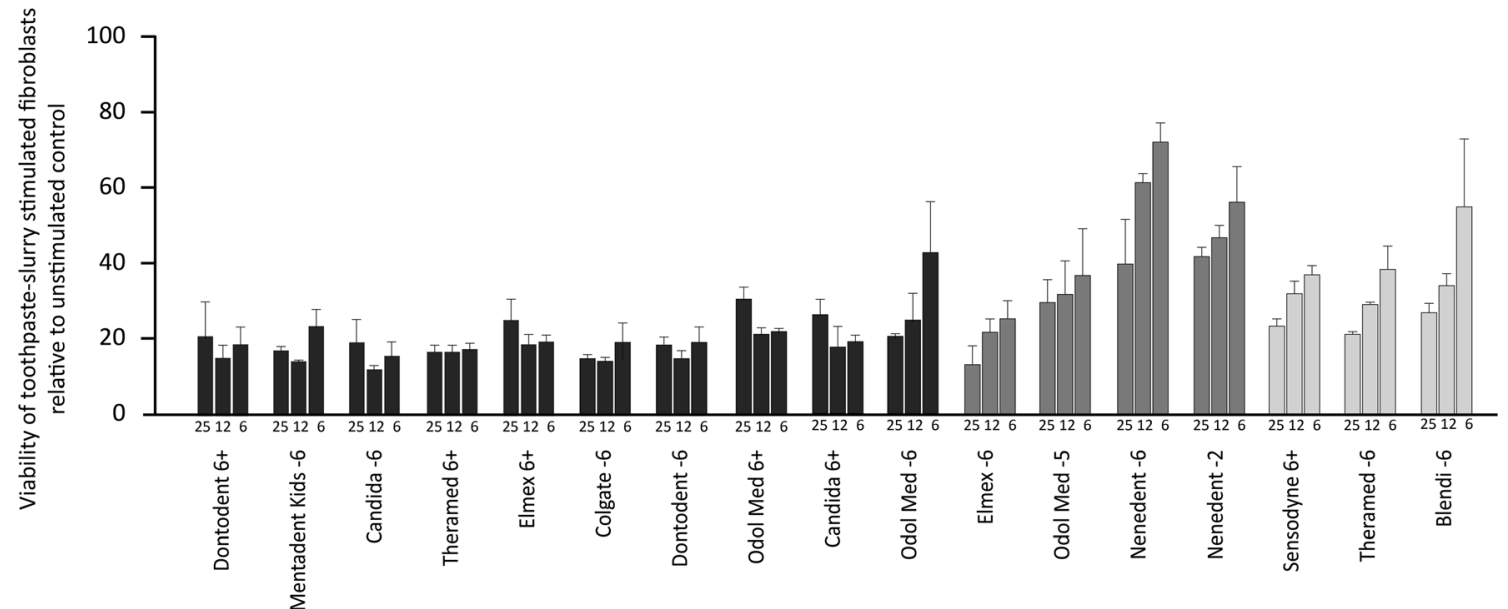

Fig. 2 Viability of oral fibroblasts after stimulation with different concentrations of toothpaste slurries from child dentifrices. Oral fibroblasts were exposed for $2 \mathrm{~min}$ to 25,12 , and $6 \%$ concentrations of uncentrifuged and unfiltered toothpaste slurries from child dentifrices. Viability was measured with an MTT assay. The 25 and $12 \%$ concentrations of uncentrifuged and unfiltered toothpaste slurries strongly reduced cell viability, almost independent of the toothpaste used. When using a $6 \%$ concentration, the results mainly support the data of the experiments when toothpaste-conditioned medium was used 


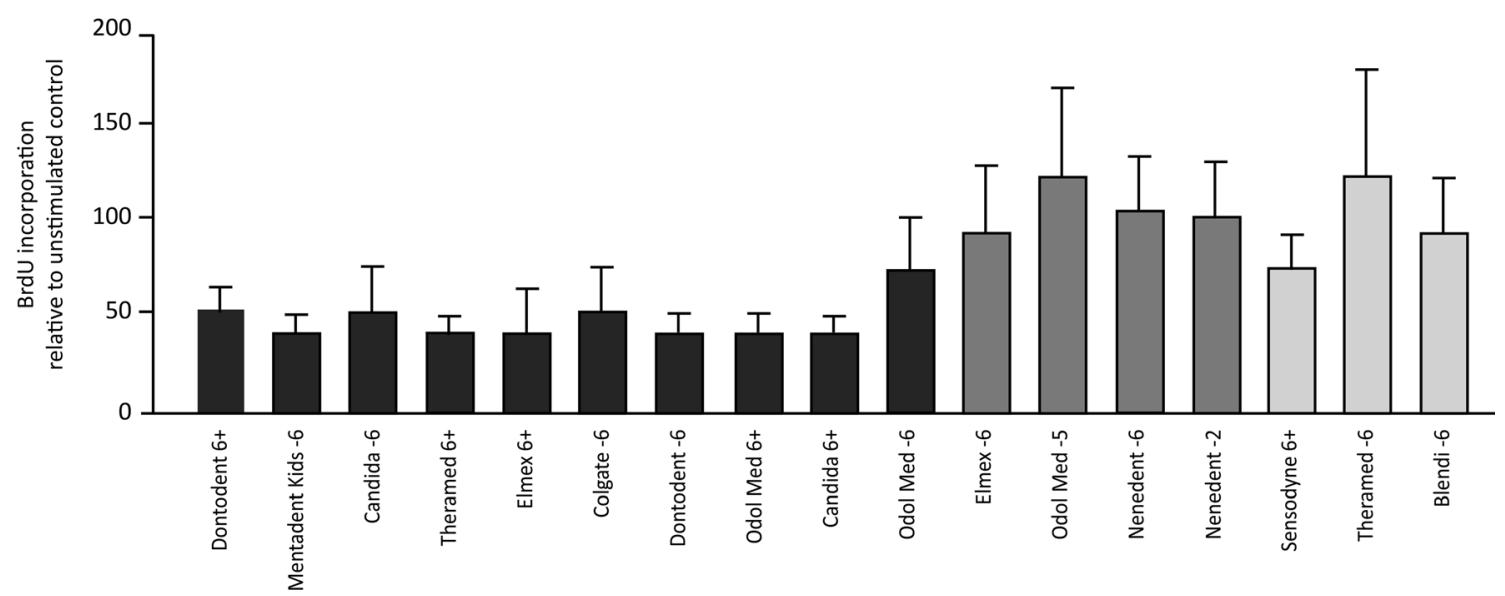

Fig. 3 BrdU incorporation by gingival fibroblasts after stimulation with a $5 \%$ concentration of the soluble compounds from child dentifrices. Proliferation was expressed as BrdU incorporation during DNA synthesis. The percentage of BrdU incorporation was normalized to untreated cells. Dentifrices that resulted in LC50 values between 5 and

\section{Discussion}

The usage of fluoridated dentifrices for daily oral hygiene is a sine qua non for maintaining healthy primary
$20 \%$ (dark-gray bars) showed in the BrdU incorporation assay similar values to dentifrices that achieved LC50 values of more than $90 \%$ (lightgray bars). Dentifrices with LC50 values below $5 \%$ exhibited decreased BrdU values (black bars)

teeth or permanent teeth. The most important factor in preventing the development of caries and reducing its incidence is regular and supervised tooth brushing with fluoride dentifrices [2]. With respect to the particular

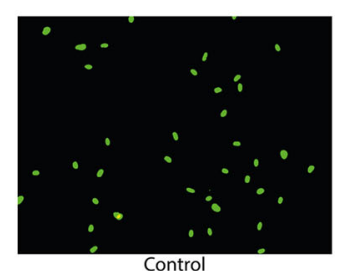

Control
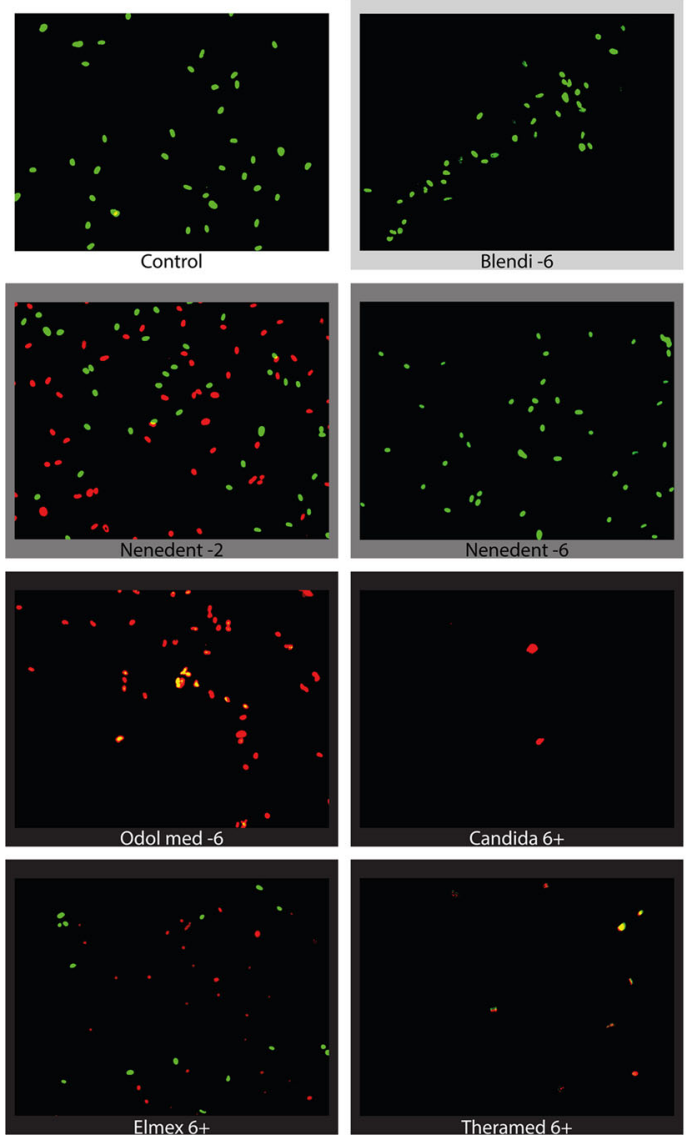

Fig. 4 Live-dead cell staining of gingival fibroblasts after stimulation with a $5 \%$ concentration of the soluble compounds from child dentifrices. Oral fibroblasts were exposed for $2 \mathrm{~min}$ to a $5 \%$
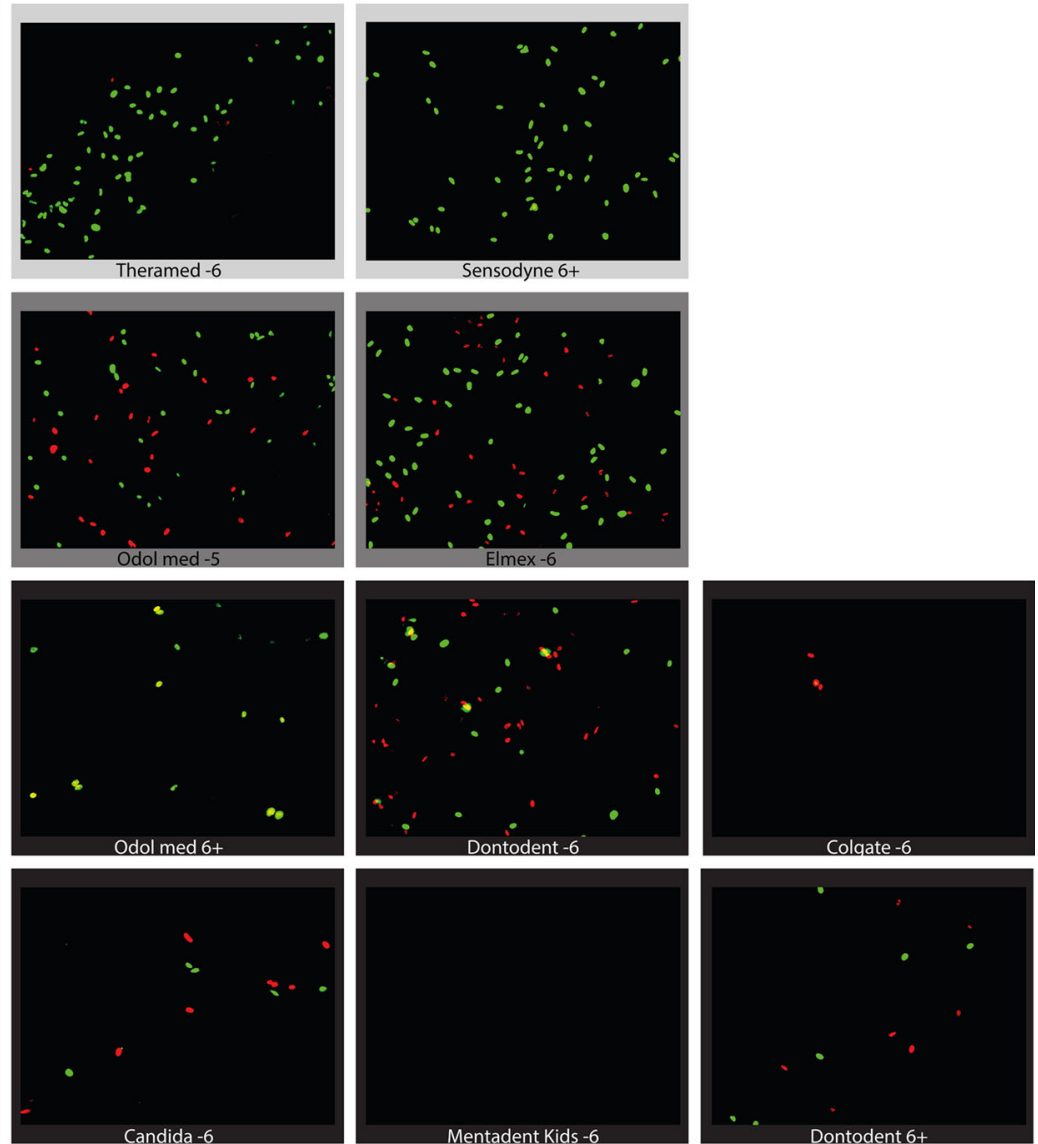

concentration of the soluble compounds from child dentifrices. Viable cells stained green, dead cells stained red 
needs of children and their primary teeth, special dentifrices have been developed [20]. The main differences between child dentifrices and dentifrices for adults are the level and type of surfactants, the type of thickening gums, flavor, color, and the amount of fluoride. While the use of fluoride in dentifrices for children is very well investigated and recommendations by international academies are available [2, 10], no investigations on child dentifrices with respect to cells of the oral cavity have been reported. This is of particular interest since dentifrices for adults have shown significant differences in the LC50 when exposed to gingival fibroblasts [17]. Six out of nine dentifrices exhibited an LC50 below $5 \%$ [17]. These results are in agreement with the present study, which showed that 10 out of 17 child dentifrices exhibited an LC50 below $5 \%$. However, conclusions on which components mediate the cytotoxic effects cannot be drawn based on the present in vitro setting.

In the present study, sodium lauryl sulfate (SLS)-containing dentifrices exhibited LC50 values below $5 \%$, which is in agreement with data from adult dentifrices [17]. These results also confirm in vitro experiments on the viability of human keratinocytes after stimulation with SLS [21]. Most child dentifrices, however, contain other detergents. Cocamidopropyl betaine (CAPB), for example, is another detergent often used in child dentifrices. In the present study, CAPB is the single detergent in three child dentifrices that achieved the highest LC50 values, but once it is mixed with another detergent, the LC50 reduced significantly. This finding is consistent with the study on adult dentifrices [17], but contrary to studies showing that CAPB and SLS have a similar cytotoxic effect in vitro $[22,23]$. One explanation for this inconsistency could be that unknown and most likely varying concentrations of CAPB were used in the indicated studies. The exact concentrations of detergents in the dentifrices that are harmful for cells will remain unclear until the exact concentrations are reported in future studies.

It is notable that only a few manufacturers use SLS in toothpaste for children compared to adult dentifrices. It is also striking that dentifrices for children up to 6 years show generally higher LC50 values than dentifrices for children over 6 years, even when they are from the same manufacturer (e.g., Dontodent, Elmex ${ }^{\circledR}$, Theramed, and Odol-med3®, but not Candida). One explanation could be that the concentration of detergents is lower in dentifrices for children up to 6 years, since children dislike foam [9]. Children over 6 years of age with a mixed dentition are moved into adult-type dentifrices with other tastes, a higher amount of fluoride, and also higher levels of foam, which probably means a higher concentration of surfactants [9]. This might be an explanation for the different results on cell viability after stimulation with dentifrices from the same manufacturer but for different age limits.

A limitation of the study is the in vitro design and therefore the results must not be clinically over interpreted. It can be assumed that higher concentrations for the same cytotoxic effects would be necessary in vivo, since neither the salivary flow nor the salivary pellicle was simulated. Furthermore, possible cell protective effects like tissue barriers or immunological aspects have not been considered. Another issue, perhaps with lesser implications, was that the child dentifrices were tested on oral fibroblasts obtained from gingival tissue from adults, instead of from children. We cannot rule out that the metabolic situation in cells from children might be different than the situation in adult's cells. However, this is not likely to have strongly influenced the results, especially since two other cell lines confirmed the results obtained with fibroblasts. One open issue is that the exact concentrations of detergents in the dentifrices are unknown and it is not possible to verify whether the detergents cause the cytotoxic effect. Furthermore, in the clinical situation, the dentifrices as a whole are in contact with the oral mucosa and not only the soluble ingredients. It might be that further ingredients of the dentifrices, both in the soluble and in the insoluble part, cause cytotoxic effects on the cells.

To enlighten the discrepancies between the in vitro situation and the clinical situation, a more clinical approach using uncentrifuged and unfiltered toothpaste slurry was also performed. However, the findings of these additional experiments are not rational enough due to multiple weaknesses. Indeed, the cells reacted generally very sensitive to the toothpaste slurry up to a concentration of $12 \%$, regardless of the toothpaste used. Merely, when lower concentrations were used, differences were noticeable, supporting the findings when toothpaste-conditioned medium was used to stimulate the cells. One explanation might be that the toothpaste slurry, independent of the ingredients, directly damages the cells due to its foam and its thicker consistency. Additionally, it should be added that the toothpaste slurry was not sterile filtered and thus the cells were possibly exposed to microorganisms. Although this should not cause immediate cell damage due to the short contact time of $2 \mathrm{~min}$. Overall, it can be said that the experimental approach using uncentrifuged and unfiltered toothpaste slurry might be clinically closer, however, too many weak points appear for valid statements.

The clinical implications may nevertheless be independent of the knowledge of which ingredients per se are responsible for the cytotoxic effects of some dentifrices. Some possible recommendations based on the results of this in vitro study are that children should use dentifrices that are designed for them and that dentifrices with the detergent cocamidopropyl betaine (without any other detergents) should be preferred amongst others. In summary, child dentifrices are more tolerable for the cells tested than has been documented for adult dentifrices. 
Approximately $12 \%$ of dentifrices for children showed LC50 values below $1 \%$ compared to $45 \%$ of dentifrices for adults, when tested on oral fibroblasts [17]. Furthermore, LC50 values more than $90 \%$ were shown in three child dentifrices, but a similar level has not been shown for fibroblasts when stimulated with adult dentifrices. Consequently, it appears to be essential to ensure that children do not use dentifrices from their parents [5] and rinsing the mouth with a small amount of water after tooth brushing might be beneficial for children with known sensitive mucosa.

Acknowledgments Open access funding provided by Medical University of Vienna. The authors would like to thank Catherine Solioz for her skillful technical assistance.

Compliance with Ethical Standards This article does not contain any studies with human participants or animals performed by any of the authors.

Conflict of interest The authors declare that they no competing interests.

Funding The work was supported by the Department of Preventive, Restorative and Pediatric Dentistry, School of Dental Medicine, University of Bern, Switzerland.

Informed consent Patients were informed about the possibility of using their teeth together with adhering tissue for research purposes and consent was obtained (Kantonale Ethikkommission Bern).

Open Access This article is distributed under the terms of the Creative Commons Attribution 4.0 International License (http:// creativecommons.org/licenses/by/4.0/), which permits unrestricted use, distribution, and reproduction in any medium, provided you give appropriate credit to the original author(s) and the source, provide a link to the Creative Commons license, and indicate if changes were made.

\section{References}

1. Li Y, Wang W (2002) Predicting caries in permanent teeth from caries in primary teeth: an eight-year cohort study. J Dent Res 81(8): 561-566

2. Walsh T, Worthington HV, Glenny AM, Appelbe P, Marinho VC, Shi X (2010) Fluoride toothpastes of different concentrations for preventing dental caries in children and adolescents. Cochrane Database Syst Rev 1:CD007868. doi:10.1002/14651858. CD007868.pub2

3. Creeth J, Bosma ML, Govier K (2013) How much is a 'pea-sized amount'? A study of dentifrice dosing by parents in three countries. Int Dent J 63(Suppl 2):25-30. doi:10.1111/idj.12074

4. Levy SM (1993) A review of fluoride intake from fluoride dentifrice. ASDC J Dent Child 60(2):115-124

5. Bennadi D, Kshetrimayum N, Sibyl S, Reddy CV (2014) Toothpaste Utilization Profiles among Preschool children. J Clin Diagn Res 8(3):212-215. doi:10.7860/JCDR/2014/7309.4165
6. Naccache H, Simard PL, Trahan L, Brodeur JM, Demers M, Lachapelle D, Bernard PM (1992) Factors affecting the ingestion of fluoride dentifrice by children. J Public Health Dent 52(4):222-226

7. Emling RC, Flickinger KC, Cohen DW, Yankell SL (1981) A comparison of estimated versus actual brushing time. Pharmacol Ther Dent 6(3-4):93-98

8. Lynch RJ (2013) The primary and mixed dentition, post-eruptive enamel maturation and dental caries: a review. Int Dent J 63(Suppl 2):3-13. doi:10.1111/idj.12076

9. Stovell AG, Newton BM, Lynch RJ (2013) Important considerations in the development of toothpaste formulations for children. Int Dent J 63(Suppl 2):57-63. doi:10.1111/idj.12083

10. European Academy of Paediatric D (2009) Guidelines on the use of fluoride in children: an EAPD policy document. Eur Arch Paediatr Dent 10(3):129-135

11. Haftenberger M, Viergutz G, Neumeister V, Hetzer G (2001) Total fluoride intake and urinary excretion in German children aged 3-6 years. Caries Res 35(6):451-457

12. Maguire A, Zohouri FV, Hindmarch PN, Hatts J, Moynihan PJ (2007) Fluoride intake and urinary excretion in 6- to 7-year-old children living in optimally, sub-optimally and non-fluoridated areas. Community Dent Oral Epidemiol 35(6):479-488. doi:10. 1111/j.1600-0528.2006.00366.x

13. Wong MC, Clarkson J, Glenny AM, Lo EC, Marinho VC, Tsang BW, Walsh T, Worthington HV (2011) Cochrane reviews on the benefits/risks of fluoride toothpastes. J Dent Res 90(5):573-579. doi:10.1177/0022034510393346

14. Lawrence LM, Farquharson A, Brown RS, Vatanka HO (2013) Oral tissue irritants in toothpaste: a case report. J Clin Pediatr Dent 38(1):75-78

15. Herlofson BB, Barkvoll P (1996) Oral mucosal desquamation caused by two toothpaste detergents in an experimental model. Eur J Oral Sci 104(1):21-26

16. Skaare AB, Rolla G, Barkvoll P (1997) The influence of triclosan, zinc or propylene glycol on oral mucosa exposed to sodium lauryl sulphate. Eur J Oral Sci 105(5 Pt 2):527-533

17. Cvikl B, Lussi A, Gruber R (2015) The in vitro impact of toothpaste extracts on cell viability. Eur J Oral Sci 123(3):179-185. doi:10. 1111/eos. 12177

18. Creeth JE, Gallagher A, Sowinski J, Bowman J, Barrett K, Lowe S, Patel K, Bosma ML (2009) The effect of brushing time and dentifrice on dental plaque removal in vivo. J Dent Hyg 83(3):111-116

19. Winterfeld T, Schlueter N, Harnacke D, Illig J, Margraf-Stiksrud J, Deinzer R, Ganss C (2015) Toothbrushing and flossing behaviour in young adults - a video observation. Clin Oral Investig 19(4): 851-858. doi:10.1007/s00784-014-1306-2

20. Churchley D, Schemehorn BR (2013) In vitro assessment of a toothpaste range specifically designed for children. Int Dent $\mathrm{J}$ 63(Suppl 2):48-56. doi:10.1111/idj.12071

21. Torma H, Geijer S, Gester T, Alpholm K, Berne B, Lindberg M (2006) Variations in the mRNA expression of inflammatory mediators, markers of differentiation and lipid-metabolizing enzymes caused by sodium lauryl sulphate in cultured human keratinocytes. Toxicol in Vitro 20(4):472-479. doi:10.1016/j.tiv.2005.09.011

22. Moore C, Addy M, Moran J (2008) Toothpaste detergents: a potential source of oral soft tissue damage? Int J Dent Hyg 6(3):193-198. doi:10.1111/j.1601-5037.2008.00307.x

23. Babich H, Babich JP (1997) Sodium lauryl sulfate and triclosan: in vitro cytotoxicity studies with gingival cells. Toxicol Lett 91(3): 189-196 